\title{
Joggyakorlat
}

\author{
KIRS ESZTER*
}

\section{Vojislav Šešelj felmentésének kritikája a felbujtás és bűnsegédlet szempontjából}

\author{
ICTY - bünsegédlet - felbujtás - nemzetközi büntetőjog - \\ háborús büncselekmények - emberiesség elleni büncselekmények
}

Vojislav Šešelj a Szerb Csetnik Mozgalom alapítója volt, amelyet 1990 decemberében betiltottak a jugoszláv hatóságok. Az 1991 februárjában létrehozott Szerb Radikális Párt elnöke, 1991 júniusától a Szerb Köztársaság Közgyűlésének választott tagja. A délszláv háborúban aktív szerepet játszott. 2016. március 31-én mentette fel az ENSZ által felállított exjugoszláv törvényszék (International Criminal Tribunal for the former Yugoslavia - ICTY). Az önkéntesek toborzását, nagy nyilvánosság előtt, politikai üléseken, interjúkban és a hadszíntéren tartott, szélsőséges nacionalista gyülöletbeszédeit úgy értékelte az ICTY elsőfokú kamarája, hogy azokból nem következik büntetőjogi felelössége háborús és emberiesség elleni büncselekményekért. A háromfös bírói tanács 2:1 arányban döntött. Flavia Lattanzi bíró figyelemre méltó kritikai észrevételekből építette fel részletes és terjedelmes különvéleményét. Az ügyészség fellebbezett az elsőfokú tanács döntése ellen, így a döntés nem jogerős.

A bíróság több felelősségi koncepció szempontjából vizsgálta az elé tárt bizonyítékokat. Felbujtóként nem találta bünösnek a vádlottat, a bünsegédi felelősségét pedig érdemben nem tárgyalta. A jelen tanulmány e két felelősségi alakzat szempontjából sorakoztat fel érveket amellett, hogy a felmentő ítéletben szereplő indokolás a vonatkozó normák alkalmazása tekintetében több sebből vérzik. A szerző a két felelősségi alakzatra nézve az ICTY joggyakorlatában kialakult sztenderdek ismertetését követően vizsgálja újra a bíróság birtokába került bizonyítékokat, és prezentálja Lattanzi bíró különvéleményének sarokpontjait.

* Dr. Kirs Eszter egyetemi docens, Miskolci Egyetem Állam- és Jogtudományi Kar, Európai és Nemzetközi Jogi Intézet; Budapesti Corvinus Egyetem Társadalomtudományi és Nemzetközi Kapcsolatok Kar, Nemzetközi Tanulmányok Intézet, kirs.eszter@gmail.com. A tanulmány az OTKA PD 105832. sz. támogatási szerződés keretein belül jött létre. 


\section{Az ICTY-nak a felbujtó és a bủnsegéd felelősségére vonatkozó sztenderdjei}

A Törvényszék joggyakorlatában körvonalazódott az összes, a Statútum által átfogott, illetve bírói jogfejlesztés útján létrejött felelősségi koncepció, azok fogalmi elemei tekintetében éppen ezért már kevésbé jellemző a még eljáró bírói kamarák újitó jellegủ vitája. Šešelj ügyében sem hajlította a meglévő definíciók kontúrjait az első fokon ítélkező kamara. A tényeket a bírói értelmezés fősodrába helyezkedve értelmezte, hol vitatható, hol hanyag módon. Éppen ezért a következő sorok rövid ismertetőjét nyújtják az ítélet megszületéséig rögzített, és az abban megerősített sztenderdeknek a felbujtó és bűnsegéd felelőssége kapcsán, hogy azok fényében történhessen meg az ítélet kritikai elemzése.

\subsection{A felbujtó felelőssége}

A felbujtó felelőssége kapcsán nem alakultak ki parázs, perdöntő viták az ICTY bírói kamarái között. A szakirodalomban is megjelenő, nemzetközi szokásjogon alapuló, általános értelmezés szerint a felbujtó arra buzdít, bátorít mást, hogy büncselekményt kövessen el. ${ }^{1} \mathrm{~A}$ felbujtó a bủncselekmény intellektuális szerzőjeként is kezelhető, s ebböl fakadóan bizonyos kontinentális jogrendekben elsődleges elkövetői státuszt nyer, és van, ahol az eshetöleges szándék (dolus eventualis) bizonyítása is elegendő a bünösség megállapításához. ${ }^{2}$ Az ICTY joggyakorlatában a részesség felelösségi keretei közé tartozik a felbujtó felelőssége, és a tudati elem szempontjából elegendő a dolus eventualis bizonyítása.

A felelösség objektív, actus reus (bünös tett) oldalára tekintve nem szükséges közvetlen okozati összefüggés bizonyitása a felbujtó magatartása és a konkrét büncselekmény elkövetése között: a felbujtás nem kell, hogy elengedhetetlen feltétele legyen a büncselekménynek. Az ICTY olvasatában elegendő annak bizonyítása, hogy a felbujtó magatartása egyértelműen hozzájárult a büncselekmény elkövetéséhez. ${ }^{3}$ Az Orić-ügyben 2006-ban hozott, elsőfokú ítélet szerint a felbujtásnak „bizonyos mértékben befolyásolnia kell a közvetlen elkövetőt”. ${ }^{4}$ Nincs szükség annak bizonyítására, hogy a felbujtótól származott a büncselekmény elkövetésének eredeti ötlete vagy terve. Szemben a népirtásra való uszítással, egyéb nemzetközi búncselekmények esetén nem kell, hogy a felbujtás nyilvános térben történjen, és arra sincs szükség az elmarasztaláshoz, hogy a felbujtó a konkrét büncselekmény közvetlen elkövetőjének címezze a buzdító szavakat.

1 WeRLE, Gerhard: Principles of International Criminal Law. T.M.C. Asser Press, The Hague, 2005, 125. Mettraux, Guénaël: Instigation. In: Cassese, Antonio (szerk.): The Oxford Companion to International Criminal Justice. Oxford University Press, Oxford, 2009, 376-376; Blaskic-ügy, 2000. március 3-i ítélet (ügyszám: IT-95-14), 280.

2 VAN SlIEDREGT, Elies: Individual Criminal Responsibility in International law. Oxford University Press, Oxford, 2012, 102-104.

3 Kvočka és mások ügy, 2001. november 2-i ítélet (ügyszám: IT-98-30/I-T), 252, 390; Kordić- és Čerkez-ügy, 2001. február 26-i ítélet (ügyszám: IT-95-14/2), 387.

4 Orić-ügy, 2006. június 30-i ítélet (ügyszám: IT-03-68-T), 271. 
A mens rea (bünös tudat) elemet vizsgálva a felbujtó szándékának arra kell kiterjednie, hogy előidézze a büncselekmény elkövetését, vagy legalábbis tudnia kell azt, hogy buzdító magatartása nagy valószínüséggel bủncselekmény elkövetését eredményezi. ${ }^{5} \mathrm{~A}$ dolus eventualis követelményéről részletesen az Orić-ítéletben értekezett az elsőfokú bírói tanács, miszerint a terheltnek el kellett fogadnia annak kockázatát, hogy a felbujtással érintett büncselekmény nagy valószínűsséggel be fog következni, csekélyebb esély van annak elmaradására. A saját magatartása tekintetében a felbujtónak tisztában kell lennie azzal, hogy az befolyást gyakorol a bủncselekmény elkövetőjére, a büncselekmény vonatkozásában pedig, ha arra nem is terjed ki az egyenes szándéka, el kell fogadnia bekövetkezésének valószínüségét. Nem kell azt bizonyítani, hogy a felbujtó pontosan látta elöre, hogy ki és milyen körülmények között fogja elkövetni a büncselekményt, elegendő a bűncselekmény típusának és alapvető elemeinek ismerete. A bủnsegédlettel egyfajta hierarchikus rendet sugallt az Orić-kamara, miszerint, ha az elkövető egyértelmüen döntött a büncselekmény elkövetéséröl, az ezt követő bátorítást, morális támogatást inkább "csak" bünsegédletként lehet értékelni. ${ }^{6}$

\subsection{A bünsegéd felelőssége}

A bűnsegédlettel kapcsolatban hosszú ideig egységes megközelítést alkalmaztak az ICTY bírói kamarái. ${ }^{7}$ Eszerint az actus reus megállapítható, ha a terhelt szándékosan támogatta, bátorította az elkövetőt, vagy morális támogatást nyújtott neki, ezzel jelentős hatást gyakorolva a büncselekmény elkövetésére. Az elkövető számára nyújtott anyagi és morális támogatás megvalósulhat például fegyverek rendelkezésre bocsátásában, katonai egységek átengedésében, az elkövetés helyszínén való jelenlétben és a büncselekmény elkövetésének jóváhagyásában, a menekülö áldozatok feltartóztatásában, vagy éppen a büncselekmények megelőzésének elmulasztásában. ${ }^{8}$ Nem szükséges annak bizonyítása, hogy közvetlen okozati öszszefüggés volt a bünsegéd cselekedete és a büncselekmény elkövetése között. A bűnsegédlet megvalósulhat a bủncselekmény elkövetése előtt, közben vagy azt követően is, és a támogatás nyújtásának nem feltétlenül kell az elkövetés helyszínén történnie. A bűnsegéd felelősségre vonásához azonban bizonyítani kell az általa elősegített büncselekmények elkövetését. A mens rea tekintetében bizonyítandó, hogy a bünsegéd tudott arról, hogy a cselekedete támogatja az elkövetőt a büncselekmények megvalósításában, és jelentős hatást gyakorol az elkövetésre. Tudatának a büncselekmények alapvető elemeit is át kell fognia, például az etnikai alapú

5 Naletilić- és Martinović-ügy, 2003. március 31-i ítélet (ügyszám: IT-98-34-T), 60.

6 Az Orić-ügyben hozott ítélet, 271-279.

7 Összehasonlításképpen lásd az angol és német joggyakorlatról: JAIN, Neha: Perpetrators and Accessories in International Criminal Law - Individual Modes of Responsibility for Collective Crimes. Hart Publishing, Portland, 2014, 155-197.

8 OlÁsolo, Héctor - Roso, Enrique Carnero: Forms of Accessorial Liability under Article 25(3)(b) and (c). In: Stahn, Carsten (szerk.): The Law and Practice of the International Criminal Court. Oxford University Press, Oxford, 2015, 581. 
üldöztetés esetében tisztában kell lennie az elkövető cselekedeteinek diszkriminatív jellegével (anélkül, hogy ő maga osztaná a hátrányos megkülönböztetéshez füzödő elkövetői szándékot). ${ }^{9}$ Ugyanakkor a konkrét, végeredményben általa elősegített bủncselekmény részleteit nem kell ismernie. ${ }^{10}$

Látszólag az actus reus (a materiális elem) kapcsán válik ketté a különböző bírói tanácsok érvelése. A bünsegéd által nyújtott segítségnek nem kell minden esetben anyagi természetünek lennie, katonai vezetői pozíció esetén például megnyilvánulhat morális támogatás, jóváhagyás formájában. Ugyanakkor alapvető feltétel, hogy a segítség jelentős hatást gyakoroljon a büncselekmény elkövetésére. ${ }^{11}$

A bünsegéd által nyújtott segítség és a büncselekmény elkövetése közötti okozati kapcsolat tekintetében térnek el a következő álláspontok:

Az egyik értelmezés szerint nincs szükség közvetlen okozati összefüggésre a búnsegéd asszisztenciája és az elkövetett büncselekmény között, amint az az általános jogtudományi vélekedésben is megjelenik. ${ }^{12}$ Például, ha a vádlott tisztában volt az elkövető sorozatos jogsértéseivel, és ennek ellenére továbbra is támogatást nyújtott neki, ezzel közreműködve a jogsértő gyakorlat fenntartásában, felelőssége bủnsegédként megállapítható. ${ }^{13}$

A másik megközelítés szerint bizonyíthatónak kell lennie, hogy a bünsegéd azzal a szándékkal biztosította támogatását az elkövető számára, hogy azzal kifejezetten a vád tárgyát képező bűncselekmény elkövetését segítse elő. A bünsegéd felelősségének megállapításához szükséges a „kifejezett irányultság” („specific direction”)

9 A bünsegéd vonatkozásában a speciális szándékot feltételező büncselekmények esetén is érvényesül az általános mens rea standard. Például Milorad Krnojelac börtönőrt bűnsegédként vonták felelősségre, mert tudata kiterjedt arra, hogy cselekedetei elösegítik a jogellenes bebörtönzéseket, és hogy az elkövetők etnikai és politikai alapon börtönözték be az érintett muszlim lakosokat. Krnojelac-ügy, 2002. március 14-i ítélet (ügyszám: IT-97-25-T), 153. Hasonló érvelés vezetett Radislav Krstić bűnsegédkénti elítéléséhez a népirtás vonatkozásában: nem nyert bizonyítást a népirtásra irányuló szándéka, az azonban igen, hogy a boszniai szerb hadsereg Drina hadtestének parancsnokaként tudott arról, hogy támogatása elősegíti a népirtás elkövetését. Krstić-ügy, 2004. április 19-i fellebbviteli ítélet (ügyszám: IT-98-33-A), 143.

10 Simić-ügy, 2006. november 28-i fellebbviteli ítélet (ügyszám: IT-95-9-A), 85; Blaškić-ügy, 2004. július 29-i fellebbviteli ítélet (ügyszám: IT-95-14-A), 45-46; Blagojević- és Jokić-ügy, 2005. január 7-i ítélet (ügyszám: IT-02-60-T), 727; Blagojević-ügy, 2007. május 9-i fellebbviteli ítélet (ügyszám: IT-02-60-A), 127; Aleksovskiügy, 2000. március 24-i fellebbviteli ítélet (ügyszám: IT-95-14/1-A), 165.

11 A Furundžija-ügyben kihirdetett ítéletben hosszas analízis található a kérdésröl. Az ügyben eljáró elsőfokú bírói tanács indoklása kiterjedt többek között a második világháborút követő ítélkezési gyakorlatra, a Schonfeld, Rohde, Synagogue, Pig-cart parade, Dachau concentration camp, Auschwitz concentration camp, Einsatzgruppen és Zyklon $B$ ügyek vizsgálatára. A második világháborút követően lefolytatott eljárásokból kiindulva állította az actus reus tekintetében, hogy a bünsegéd által nyújtott segítségnek nem kell minden esetben anyagi természetűnek lennie: a szükséges státusz megléte esetén morális támogatás, jóváhagyás formájában is megjelenhet. Ugyanakkor hangsúlyozta, hogy a támogatásnak jelentős hatást kell gyakorolnia a bűncselekmény elkövetésére. Furundžija-ügy, 1998. december 10-i ítélet (ügyszám: IT95-17/1-T), 190-257.

12 CASSESE, Antonio: International Criminal Law. Oxford University Press, Oxford, 2008, 214-218; SLIEDREGT 2012: i. m., 112-124; Werle: i. m., 125-127; OHLIN, Jens: Aiding and abetting. In: Cassese, Antonio (szerk.) 2009: i. m., 239-240.

13 Aleksovski-ügy, 2000. március 24-i fellebbviteli ítélet (ügyszám: IT-95-14/1-T), 169-172; Mrkšić-ügy, 2009. május 5-i fellebbviteli ítélet (ügyszám: IT-95-13/1-A), 159; Lukić és mások ügy, 2012. december 4-i fellebbviteli ítélet (ügyszám: IT-98-32/1-A), 424. 
elemének bizonyítása. (Ezzel gyakorlatilag a tudati elem mércéjét emelték a vonatkozó bírói kamarák.) Ezen érvelés alapján mentették fel másodfokon Momčilo Perišićet, a jugoszláv hadsereg korábbi vezérkari főnökét. ${ }^{14}$

A Šainović-ügyben 2014-ben hozott ítéletével - a második világháborút követően hozott bírói döntések, az ICTY saját esetjoga és az állami gyakorlat alapos vizsgálatát követően - a Fellebbviteli Tanács felülírta a Perišić-ügyben másodfokon hozott döntés alapját képező megközelítést, miszerint a „kifejezett irányultság” szükséges a bűnsegédi felelősség megállapításához, és a korábbi megközelítést tette irányadóvá a jövőre nézve. A második világháborút követő ítéletek és a szokásjog elemzése arra a következtetésre juttatta, hogy a „kifejezett irányultság” kritériumának követelése nem jelenik meg az állami bíróságok egyöntetü és tartós gyakorlataként. Pusztán annak bizonyítása szükséges, hogy a vádlott tudta, hogy asszisztenciája jelentős mértékben elősegítette a büncselekmény elkövetését. ${ }^{15}$

\section{A felbujtó és a bünsegéd felelőssége a Šešelj-ítéletben}

\section{1. Šešelj nem felbujtó}

Az ügyben eljáró bírói tanács az alkalmazandó jogi sztenderdek körvonalazásában igazodott az addig kialakult esetjoghoz. Az actus reus szempontjából annak bizonyíthatóságát követelte meg, hogy a terhelt ösztönző magatartása közrehatott a büncselekmények elkövetésében. A fent ismertetett, fennálló sztenderdektöl eltérően hangsúlyozta a felbujtói felelősség megállapíthatósága tekintetében, hogy a felbujtónak különböző meggyőzési módszereket kellett alkalmaznia: fenyegetést vagy a büncselekmények elkövetőinek tett ígéreteket. A mens rea vonatkozásában pedig vagy arra irányuló szándék bizonyíthatóságát követelte meg, hogy a közvetlen elkövetőt a bủncselekmény elkövetésére bírja, vagy legalább annak tudatát, hogy az elkövető a bűncselekményt a felbujtó magatartás hatására nagy valószínüséggel elköveti. ${ }^{16}$

A meggyőzési módszerek alatt (különösen arra tekintettel, hogy a Šešelj ügyében ítélkező kamara példálózva említette a fenyegetés, illetve ígéretek módszerét) érthetünk széles körben véve bármely meggyőzési technikát, ami alkalmas a fizikai elkövetők befolyásolására. Másfelől, bár az alkalmazandó jogról szóló fejezeten belül nem említi, utóbb, a tények értékelése során megkövetelte az okozati összefüggést a felbujtói magatartás és a konkrét büncselekmények között. ${ }^{17} \mathrm{Ez}$ a megközelítés vitatható, hiszen a fent ismertetettek szerint a népirtásra való uszítással szemben,

14 Tadić-ügy, 1999. július 15-i fellebbviteli ítélet (ügyszám: IT-94-1-A), 229; Perišić-ügy, 2013. február 28-i fellebbviteli ítélet (ügyszám: IT-04-81-A), 26-36. Lásd erről bővebben KıRs Eszter: Bünsegédlet a nemzetközi büntetőjogban és az elhibázott Perišić-ítélet. In: Csapó Zsuzsanna (szerk.): Emlékkötet Herczegh Géza születésének 85. évfordulójára - A ius in bello fejlődése és mai problémái. Pécsi Tudományegyetem Államés Jogtudományi Kar, Pécs, 2013, 143-156.

15 Šainović és mások ügy, 2014. január 23-i fellebbviteli ítélet (ügyszám: IT-05-87-A), 1617-1651.

16 Šešelj-ügy, 2016. március 31-i ítélet (ügyszám: IT-03-67-T), 294-296.

17 A Šešelj-ügyben hozott ítélet, 333, 343. 
egyéb nemzetközi büncselekmények esetén az elmarasztaláshoz nem szükséges annak bizonyítása, hogy a felbujtó a konkrét bủncselekmény közvetlen elkövetőjének címezze a buzdító szavakat, illetve hogy ez közvetlenül eredményezze a bűncselekmény elkövetését.

Mindezek fényében a következő szempontokból érdemes megvizsgálni a Šešelj ügyében hozott ítéletet: (1) Volt-e olyan pozícióban a terhelt, és alkalmas eszközöket alkalmazott-e ahhoz, hogy jelentős hatást gyakoroljon a bűncselekmények elkövetöire? (actus reus) (2) A terhelt beszédei, megnyilvánulásai tartalmaztak-e buzdítást nemzetközi bűncselekmények elkövetésére? (actus reus) (3) Tudott-e arról a terhelt, hogy a felbujtói magatartása jelentős hatást gyakorolt a fizikai elkövetőkre, és hogy a felbujtói megnyilvánulásban megjelenő bűncselekmények elkövetésére nagy valószínűséggel sor kerül? (mens rea).

\subsubsection{Befolyásolási képesség}

A bírói kamara elé került bizonyítékok egyértelmüen demonstrálták, hogy a vádlott jól ismerte a propaganda módszereit és a tömegek pszichológiáját. Szakértő tanú hívta fel a figyelmet arra, hogy a vádlott 1990 és 1994 között tartott beszédeit a „xenofób nacionalizmus" jellemezte, valamint egy sor közismert, tömegek meggyőzését célzó propagandatechnika, mint a félelemkeltés, az áldozatiság érzetének előhívása, repetitív panelek, negatív sztereotípiák, valamint a jelenségek valóságot torzító elnevezése (mint az etnikai tisztogatás helyett „civilizált lakosságcsere” említése). A propaganda módszereinek elmélyült ismeretét igazolják többek között Šešelj 2002-ben publikált „A szerb nacionalizmus ideológiája” címü könyvének vonatkozó passzusai, valamint a fasizmus tömegpszichológiájára irányuló tanulmányai. ${ }^{18}$

Önmagában az, hogy a meggyőzés, a tömegmanipuláció módszereinek mestere, nyilvánvalóan nem lett volna elegendő a jelentős hatás kifejtésének képességéhez, annak alapját képezte magas hatalmi pozíciója is. A Szerb Radikális Párt elnökeként, a Slobodan Milošević-csel és az általa alapított Szerbiai Szocialista Párttal 1993 őszéig ápolt jó viszony és a koalíciós kormányzásban való részvétel adta hatalmi dominancia észszerủen nem vitatható. Ezentúl a csetnik vajda által toborzott nacionalista önkéntesek félistenként tekintettek rá. A bíróság számos bizonyíték birtokába jutott, ${ }^{19}$ amelyek arról tanúskodtak, hogy az önkéntesek ideológiai vezérüknek tartották, meg nem kérdőjelezve beszédei „igazságát”.

A beszédeit széles körben terjesztették minden lehetséges médiaorgánum közvetítésével, legyen az televízió, rádió vagy írott sajtó. A politikai jellegủ eseményeken és az önkéntesei toborzása közben, valamint a hadszíntéren tett látogatásai során tartott beszédei pedig közvetlenül is elérhették a fizikai elkövetőket. Vitathatatlan, hogy Šešelj üzenetei eljutottak az elkövetőkhöz, és jelentős hatást gyakoroltak rájuk.

18 A Šešelj-ügyben hozott itélet, 297-299.

19 A Šešelj-ügyben hozott itélet, 341. 


\subsubsection{A beszédek tartalma}

A következő kérdés, hogy az elkövetöket elérő és rájuk jelentős hatást gyakorló szövegek, beszédek tartalmaztak-e felhívást olyan nemzetközi büncselekmények elkövetésére, amelyekre aztán sor került. A felbujtói felelősség megállapíthatóságáról értekezve részletesen tárgyalja az ítélet Šešelj beszédeinek tartalmát és azok körülményeit. A politikai beszédeken túl nyilvánvalóan különös jelentőséggel bírt a felbujtás megítélésében, hogy milyen szavakkal buzdította a hadszíntéren meglátogatott önkéntes katonákat. Ennek feltérképezése során a bírói tanács különböző sajtóorgánumok tudósításaira és tanúvallomásokra hagyatkozhatott.

Számos forrás árulkodott arról, hogy 1991 novemberében, Vukovár eleste előtt „egy usztasa sem hagyhatja el Vukovárt élve!" és „harcoljatok hősiesen ellenük, ne gyakoroljatok kegyelmet!" üzeneteket hordozó felszólalásokat tett a katonák elött, illetve a terepen közlekedve, megafonba kiabálva. Figyelembe vette a bírói kamara többsége azt az esetet is, amikor tanúvallomások szerint a terhelt uszító beszédeit követően a jelenlévő körülbelül 50 önkéntes a levegőbe lőtt az „egy usztasa sem hagyhatja el élve Vukovárt" felkiáltás kíséretében, ezzel fejezve ki tetszésüket és egyetértésüket. ${ }^{20}$ Šešelj vukovári jelenlétét saját dokumentumfilmben való szereplése és korábbi, a Milošević-ügyben tett vallomása igazolta. Elmondása szerint az 'usztasa' kifejezéssel kizárólag a helyi szerb lakosságot támadó szélsőséges horvátokra utalt.

A beszédek esetenkénti vizsgálatát követően a bírói kamara arra a megállapításra jutott, hogy egyfelöl nem lehet hiteles forrásnak tekinteni az összes médiaorgánumot, ahonnan merítették a tudósításokat, valamint a tanúvallomások alapján sem lehetett egyértelmüen azonosítani Šešelj beszédeinek pontos tartalmát. Éppen ezért nem lehet kizárni annak lehetőségét, hogy a beszédek a konfliktus hevében a csapatok harci kedvének gerjesztését célozták, nem pedig a kegyetlenkedésre való felhívást. ${ }^{21}$

Mali Zvornikban 1992 márciusában Šešelj a következőképp szónokolt: „Kedves csetnik testvéreim, különösen ti, a Drinán túl, ti vagytok a legbátrabbak! Ki fogjuk söpörni a pogányokat Boszniából, és megmutatjuk nekik az utat Kelet felé, ahová tartoznak!"A többségi véleményben szereplö indoklás szerint ez a beszéd nem elegendő bizonyíték az etnikai tisztogatásra való felhívásra, valamint nem vált bizonyítottá, hogy a beszédnek bármi közvetlen, konkrét szerepe lett volna a büncselekmények elkövetésében. ${ }^{22} \mathrm{~A}$ felbujtó magatartás és az abban megjelenő büncselekmények közötti közvetlen okozati összefüggés bizonyítása a fent ismertetett sztenderdek szerint nem szükséges. (Bár a beszéd indulatfokozó erejéről árulkodik, hogy az itt tárgyalt, „nacionalista” esemény ellen demonstráló, hozzávetölegesen 1000 fős tömeg és a szimpatizálók között tömegverekedés tört ki 5-6 perccel a beszéd után. ${ }^{23}$ ) $A$ beszéd fent idézett részletét köznapi jelentés szerint értve nehezen képzelhető el

\footnotetext{
20 A Šešelj-ügyben hozott itélet, 314.

21 A Šešelj-ügyben hozott itélet, 306-318.

22 A Šešelj-ügyben hozott itélet, 319-328.

23 A Šešelj-ügyben hozott ítélet, 322-323.
} 
más észszerủ értelmezés, mint hogy a szónok a boszniai muszlim lakosság elüzésére gondolt. A többségi bírói vélemény szerint nem állapítható meg, hogy a terhelt „etnikai tisztogatásra” gondolt volna. ${ }^{24}$ A kérdéses események idejére köztudott volt az etnikai tisztogatás elkövetésének súlya és megítélése a nemzetközi közösség által. Reális vajon az elképzelés, hogy potenciálisan bármely tájékozott katonai vagy politikai vezető kifejezetten „etnikai tisztogatásra” buzdítson nyilvánosan? A többségi véleményt alkotók szerint igen.

1992. május 6-án Hrtkovci községben arról szónokolt a terhelt, hogy nincs ott helye a horvátoknak, csak azoknak a „katolikus szerbeknek”, akik a szerbek oldalán hullatják vérüket. Azokat a horvátokat, akik még nem hagyták el a települést, buszokkal fogják elszállítani a horvát határra. A beszéde végén „horvátok, takarodjatok Horvátországba!” és „ez Szerbia!” felkiáltásokat skandált a hallgatóság. A bíróság ebben az esetben már elismerte, hogy ez a beszéd egyértelműen a kitoloncolásra irányuló felhívást tartalmazott, azonban ismét közvetlen okozati összefüggést követelt meg; következtetése szerint azt nem sikerült bizonyítania az ügyészségnek, hogy emiatt menekültek el a településről a horvátok, és váltak üldöztetés áldozatává. ${ }^{25}$ A bírói tanácsnak az utóbbi szempontot - a korábban több esetben írottak szerint az irányadó sztenderdek alkalmazása során irrelevánsnak kellett volna tekintenie. Az a kérdés pedig, hogy okozhatta-e a beszéd a deportálás búncselekményének elkövetését, a továbbiakban még szóba kerül, a terhelt tudatának perspektívájából.

A döntésben két további, a szerb parlamentben 1992 áprilisában elhangzott beszéd jelenik meg, melyeket egyértelmüen háborús büncselekmények elkövetésére való buzdítás terhelti magatartásaként értékelt. Ezekben a hozzászólásaiban azt a nézetét fejtette ki Šešelj, hogy a horvát lakosság elüzése felfogható egyfajta ellenintézkedésként, válaszul a szerbekkel szemben foganatosított, diszkriminatív intézkedésekre. A képzett politikus elfeledkezett arról az alapvető normáról, miszerint ellenintézkedés címén sem megengedett az alapvető emberi jogi és humanitárius jogi szabályok megsértése. Ez azonban a jelen soroknak nem tárgya, így visszakanyarodva a felbujtói felelősség kérdéséhez: a bírói kamara e beszédek esetében is az okozati összefüggés hiányára hivatkozott. A követelmény irrelevanciáján túl megjegyzendő, hogy a terhelt felelős politikusi minőségében tette a nevezett nyilatkozatokat, amelyek a legmagasabb szinten születő politikai döntésekre voltak kihatással.

Flavia Lattanzi további eseteket, beszédeket foglalt különvéleményébe, melyekkel a terhelt az ő értelmezésében a horvát és muszlim lakosság üldözésére és deportálására uszított, és nyíltan buzdított gyűlöletre, erőszakra és etnikai tisztogatásra. Egy 1992. április 16-i sajtótájékoztatón a következőképpen nyilatkozott: „Egyértelmü üzenetet küldtünk a horvátoknak, semmi keresnivalójuk Belgrádban, mihamarabb el kell tünniük innen.” Egy 1992. április 22-i interjúban: „Több okból utasítanám ki a horvátokat. Mindenekelőtt a horvátok egyáltalán nem lojális lakói Szerbiának, a nagy többségük a Horvát Demokratikus Közösség külföldi kollaboránsa. [...] Megtorlás lesz ez a horvátokkal szemben cserébe azért, hogy Tuđman kitoloncolt 160000 szerbet." Beszédeiben rendszeresen használt lealacsonyító ki-

24 A Šešelj-ügyben hozott itélet, 328.

25 A Šešelj-ügyben hozott itélet, 329-333. 
fejezéseket, miszerint a horvátok „,becstelenek”, „bünözők”, „,örténelem nélküli nép”, „egerek”, „vámpírok”, a muszlimok pedig „pogányok”. „Patakokban fog folyni a vér.” „[A szerbeké] kiváló fegyverek, ki fogják folyatni a horvátok szemeit és leszakítják a fejüket a testükről." ${ }^{26}$ Lattanzi érvelése szerint nem lett volna szükség annak bizonyítására, hogy Šešelj minden egyes konkrét bủncselekmény elkövetésére buzdítson, és hogy ennek közvetlen eredményeként kövessék el a konkrét búncselekményeket. Elegendő lett volna annak bizonyítása, hogy a beszédek egyértelműen a horvát és muszlim közösség tagjai ellen irányultak, és a hallgatóság az ellenük alkalmazott erőszakra való buzdításként értelmezte őket. ${ }^{27}$

A többségi álláspont arra hivatkozott, hogy Šešelj beszédei a folyamatban lévő konfliktus hevében a csapatok harci kedvének gerjesztését célozták, nem pedig a kegyetlenkedésre való felhívást. Azzal kapcsolatban tehát nincs kétség, hogy Šešelj ügyében feltétlenül figyelembe kell venni a fegyveres konfliktus és a régióban élő etnikai csoportok közötti feszültség kontextusát. A konfliktus helyzetében még nagyobb súllyal esik latba egy-egy, az ellenségeskedésben részt vevők által nagyra becsült politikai vagy katonai vezető megnyilvánulása. Akár a politikai döntéseket potenciálisan befolyásoló, parlamenti felszólalásokat, akár a sajtónak adott nyilatkozatokat, akár a fronton hadban állóknak szóló beszédeket nézzük, a nemzetközi bűncselekmények elkövetésére való buzdítás súlyos általános következményekkel jár. Ha a konkrét alapbüncselekményekre nézve a közvetlen okozati összefüggést nem is lehet bizonyítani (amit a jog a fentiek szerint elő sem ír), akkor is nyilvánvaló tény, hogy a széles körben elismert vezető szavai meghatározó iránymutatást jelentettek a fizikai elkövetők cselekedeteire. A beszédek tartalma pedig a jelen esetben kétségkívül bővelkedett szélsőséges, erőszakra és nemzetközi bủncselekményekre buzdító fordulatokban.

\subsubsection{Eshetöleges szándék}

A felelősségi koncepció ismertetése keretében írtak szerint a felbujtó szándékának arra kell kiterjednie, hogy előidézze a büncselekmény elkövetését, vagy legalábbis tudnia kell annak nagy valószínúségéről, hogy buzdító magatartása bűncselekmény elkövetését eredményezi. A felbujtó szándéka tehát lehet eshetöleges.

A beszédek tartalmának tárgyalása során szóba került Vukovár elestének esete, amikor a terhelt hadszíntéren tett, 1991 novemberi látogatása során tartott uszító beszédeit követően a jelenlévő önkéntesek a levegőbe lőttek az „egy usztasa sem hagyhatja el élve Vukovárt" felkiáltás kíséretében, ezzel fejezve ki tetszésüket és egyetértésüket. A kamara birtokában volt azt alátámasztó bizonyíték is, hogy Šešelj 1992. májusi Hrtkovci községben tartott beszédét hallva, a tömeg a "Kifelé usztasák!” és „Horvátok, menjetek Horvátországba, ez Szerbia!” szólamokat kántálta. Figyelemmel arra, hogy Šešelj jól ismerte a propaganda módszereit és a tömeg pszichológiáját, naiv feltételezés lenne azt állítani, hogy ne lett volna tudatában annak, hogy beszédei jelentős hatást gyakorolnak a jelenlévő és a médián keresztül elért

26 Šešelj-ügy, 2016. március 31-i ítélet, Flavia Lattanzi különvéleménye (ügyszám: IT-03-67-T), 99-101.

27 A Šešelj-ügyben hozott itélet, különvélemény, 104, 113. 
hallgatóságra. Az etnikai tisztogatásra uszító szavakat olyan kontextusban használta, amelyben nem volt kétséges, hogy az uszításban megjelenő büncselekmények elkövetése reálisan várható a megszólított önkéntesektöl, hadviselőktől. Tudnia kellett arról, hogy nagyon valószínü, hogy buzdító magatartása bűncselekmények elkövetését eredményezi. Ráadásul később, a diszkriminatív intézkedések, a deportálás gyakorlata folyamán, mindezek ismeretében sem változtatott beszédei tartalmán és hangnemén.

\section{2. Šešelj nem bünsegéd}

A Šešelj ügyében eljáró bírói kamara nem helyezkedett szembe a Šainović-ügyben hozott másodfokú ítélet érvelésével, hangsúlyozva, hogy a felelősség megállapításához bizonyítandó, hogy a terhelt gyakorlati vagy morális támogatása érdemi hatást gyakorolt az elkövetők magatartására, és a bünsegédnek tudnia kellett arról, hogy hozzájárult a bűncselekmények elkövetéséhez, valamint tisztában kellett lennie a büncselekmények alapvető elemeivel. Mindez nem jelenti azt, hogy tudnia kellett az egyes konkrét bűncselekményekről. A bírói tanács az ügyészi és védői érvek, valamint az alkalmazandó sztenderd rövid ismertetését követően nemesnek, illetve gondosnak nem nevezhető egyszerüséggel tett hárombekezdésnyi pontot a bünsegédletről szóló „mondata” végére: (1) A bűnsegédi felelősség esetén ugyanazokkal a tényekkel kellene operálni, mint amelyeket már elemzett a bünszervezeti felelősség kapcsán. (2) A nacionalista propaganda önmagában nem büntetendő, és az önkéntesek toborzása lehetett a háborús törekvések legitim támogatásának manifesztációja. (3) Az ügyészség nem sorakoztatott fel arra utaló bizonyítékokat, hogy a beszédek érdemben elösegítették a büncselekmények elkövetését. ${ }^{28}$

Egyszerüen fogalmazva a bírói kamara elmulasztotta részletesen indokolni döntését a rendelkezésre álló bizonyítékok fényében a bünsegéd felelősségének szempontjából. Ez abban az esetben, amikor az ezt megelőző pontokban a kamara megállapította a terhelt felelősségének hiányát az összes többi felelősségi alakzat esetén, komoly hiányosságot teremt az ítélet indoklásában. A bírói munka hanyagságának súlyát csak tetézi Šešelj uszító propagandában és önkéntesek toborzásában megnyilvánuló tevékenységének megítélése az érintett társadalmakban és a nemzetközi közösségben. Félreértés ne essék, a pártatlan és független bíróság döntését nem diktálhatja a társadalomban született „ítélet”, azonban a Šešeljhez hasonló ikonikus szerepet betöltő terhelt esetén súlyozott jelentősége van a kimerítő, minden releváns részletre kiterjedő indoklásnak. Arra invitálom most az olvasót, hogy tekintse át az elsőfokú kamara fent megnevezett „érveit”, amelyek alapján megállapította a vádlott, mint potenciális bünsegéd bünösségének hiányát.

28 A Šešelj-ügyben hozott itélet, 351-357. 


\subsubsection{A tényeket már elemezték}

Az elsőfokú kamara többségi döntése szerint a bủnsegédi felelősség alaposabb indoklását szükségtelenné teszi a tény, hogy a rendelkezésre álló bizonyítékokat más felelősségi koncepciók szempontjából - már elemezték. Az igaz, hogy mind a fizikai elkövetés, mind a bűnszervezeti és felbujtói felelősség lehetőségét vizsgálva tárgyalta a bírói kamara Šešelj beszédeit és a toborzás tényét. Ez azonban nem mentesíti a bíróságot a kötelezettség alól, hogy indoklásában újraértékelje a tényeket, egy teljesen más feltételrendszerrel alkalmazott felelősségi koncepció szempontjából.

A bünszervezet tagjaként megállapított felelősség alapalakzata, amelyet a Šešelj ügyében eljáró kamara vizsgált, feltételezi az egyenes szándékot, amely a bünszervezet tagjai közös büntervének megvalósítására irányul, valamint azt, hogy a bünszervezet bíróság előtt álló tagja érdemben közremüködjön abban. A bűnszervezeti felelősségi koncepciót megalkotó, Dusko Tadić ügyében eljáró bírói tanács különbséget is tett indoklásában a két felelősségi koncepció között. Megállapítása szerint a búnsegéd esetében nincs szükség közös büntervre az elkövető és a bűnsegéd között. Az alanyi oldal, a terhelt tudata tekintetében megerősítette a legszélesebb körben elfogadott megközelítést, miszerint nem szükséges szándékosságot bizonyítani a bűnsegéd oldalán, elegendő az arra vonatkozó tudás, hogy a segédlet elősegítette a büncselekmény elkövetését. ${ }^{29}$ Ebböl nyilvánvalóan következik, hogy egy adott eset körülményei és az ügyben rendelkezésre álló bizonyítékok lényegesen más megvilágításba kerülnek a két különböző felelősségi koncepció vizsgálata esetén.

Ha arra a következtetésre jutott is a bíróság, hogy nincsenek minden kétséget kizáró bizonyítékok arra, hogy a terhelt osztotta az etnikai tisztogatásra irányuló bủnterv szándékát, illetve hogy egyáltalán létezett a bünterv, köteles lett volna érdemben értékelni Šešelj beszédeit, azoknak az általa toborzott önkéntesekre gyakorolt hatását abból a szempontból, hogy jelentős morális támogatást nyújtottak-e a bizonyított büncselekmények elkövetőinek.

A felbujtói felelősség kapcsán a bírói tanács többsége közvetlen okozati összefüggést keresett a beszédek és a konkrét büncselekmények elkövetése között. E szigorú és szük fókuszú értelmezés a fent írtak szerint a felbujtás felelősségi koncepciója esetén is kritika tárgyát képezi, és a bủnsegéd felelőssége szempontjából is leszögezhető, hogy a bünsegéd felelősségének megállapításához nem szükséges közvetlen okozati összefüggés bizonyítása. A bíróságnak indokolnia kellett volna döntését abban a tekintetben is, hogy jelentős támogatást nyújtott-e a terhelt az elkövetőknek, annak tudatában, hogy ezzel elösegíti olyan büncselekmények elkövetését, amelyek alapvető elemeivel tisztában volt.

Végül a közvetlen elkövetői minőség feltételrendszere értelemszerűen tér el lényegesen a bűnsegédletétől. Az, hogy nem került bizonyításra, hogy Šešelj személyesen részt vett volna a horvát és muszlim lakosok kitelepítésében, ${ }^{30}$ nem zárja ki annak lehetőségét, hogy a deportálást végrehajtó fizikai elkövetőket ösztönözte, az etnikai tisztogatásra buzdító beszédeivel morális támogatásáról biztosítva őket.

29 A Tadić-ügyben hozott fellebbviteli itélet, 229.

30 A Šešelj-ügyben hozott itélet, 282-285. 
Következésképpen akár a bünszervezeti, akár a felbujtói vagy a közvetlen elkövetői bünösséget vesszük tekintetbe, elmondható, hogy a bünsegéd felelőssége eltérő kritériumok mentén állapítható meg. Ebből adódóan a bírói kamarának egyértelmű és meggyőző konklúziókkal kellett volna szolgálnia a bűnsegédi felelősség megállapíthatóságának kérdésében.

\subsubsection{A legitim háborús törekvések}

A többségi döntés szerint nem kizárható, hogy Šešelj a háborús törekvések szolgálatában, legitim módon szónokolt provokatív, lelkesítö, feltüzelő hangnemben, és így sorozott önkénteseket. ${ }^{31} \mathrm{Ha}$ ezt az állítást elfogadjuk is, ez önmagában nem zárja ki a búnsegéd felelősségi koncepciójának alkalmazását. A bűnsegéd azon magatartásának, amellyel materiális vagy morális támogatást nyújt a bünelkövetőnek, nem kell jogellenes tevékenységnek lennie. Ha magatartásával, amely egyébként jogszerünek tekinthető, elősegítette az elkövetést, és ennek tudatában volt, megállapítható a felelőssége.

Bár az önkéntesek sorozását követően nem állt fenn elöljáró-alárendelt viszony az önkéntesek és Šešelj között, több körülmény utal arra, hogy tudhatott az elkövetett büncselekményekröl. Ahogy Lattanzi okirati bizonyítékokra hivatkozva hangsúlyozza különvéleményében, Šešelj maga nevezett ki parancsnokokat az önkéntesek közül, folyamatos kapcsolatban maradt az általa sorozott önkéntesekkel, rendszeresen látogatta őket a hadszíntéren, és jelentéseket kapott a parancsnokaiktól. A bíróság birtokába került olyan bizonyíték is, amely szerint az önkéntesek által elkövetett büncselekményekröl értesülve nem tett semmit az elkövetők felelősségre vonása érdekében, ehelyett más operatív zónába helyeztette át őket. A sorozás folyamatában nem írta elő a jelentkezők előéletének ellenőrzését, holott köztudott volt, hogy az önkéntesek soraiban számos büntetett előéletű jelentkező volt, egyetlen önkéntesekhez címzett beszédében sem szögezte le a humanitárius jogi normák tiszteletben tartásának kötelezettségét, ellenben szisztematikusan indoktrinálta őket a szélsőséges nacionalista ideológián alapuló beszédeivel. ${ }^{32}$ Minthogy a sorozást követően az általa sorozott önkéntesek a fegyveres erők kötelékébe kerültek, Šešelj parancsnoki felelőssége - miszerint elmulasztotta volna megtenni a szükséges és elvárható intézkedéseket az alárendeltjei felelősségre vonása, illetve a büncselekmények megelőzése érdekében - nem volt megállapitható mind a hierarchikus viszony, mind a de facto parancsnoki pozíció bizonyíthatósága hiányában, a fenti tények azonban elegendőnek bizonyulhattak volna a bünsegédi felelösség tudati elemének megállapításához.

${ }^{31}$ A Šešelj-ügyben hozott itélet, 355.

${ }^{32}$ A Šešelj-ügyben hozott itélet, különvélemény, 139-140. 


\section{Zárógondolat}

Könnyen tünhetnek a fenti sorok vádbeszédnek, illetve fellebbviteli beadványnak, a szerző a kritikai észrevételek összefoglalása során nem rejtette véka alá ellenérzéseit a felmentés mögötti bírói érvelés kapcsán. Az ítélet indoklásában hibák és hiányosságok éktelenkednek, ezek állnak Vojislav Šešelj felbujtói és bűnsegédi felelősség alóli felmentése hátterében.

Ez azonban nem hatott ki arra, hogy Šešelj felmentő itéletet lobogtatva térhetett vissza a hazai politikai szférába, fennhangon hirdetve, hogy „nem érzi magát felelösnek semmiben az 1990-es években történt események kapcsán”. ${ }^{33}$ Ezzel szemben a leköszönő horvát miniszterelnök, Tihomir Orešković deklarálta, hogy Šešelj persona non grata, nem kívánatos személy Horvátországban, és ha átlépi az ország határát, letartóztatják. ${ }^{34}$ Felmentése növelte a népszerűségét Szerbiában, elősegítette a vezetése alatt álló Szerb Radikális Párt törvényhozásba való visszatérését, és annak színeiben indult a 2017-es szerbiai államföválasztáson. Populista fordulatokkal szónokol újfent a Nagy-Szerbia álmáról. 2017 februárjában például Szerbia legnépszerübb kereskedelmi televíziócsatornáján, az egyébként szórakoztató tartalmat közvetítő TV Pinken szerepelt. Egy teljes órát kapott, hogy közben ízléstelen poénokat csattogtasson az ICTY afrikai származású bíráiról, a „,degenerált majmokról" és a háborús búncselekmények „kitalált” áldozatairól. A stúdióban ülő közönség nevetett és tapsolt. Éppen úgy, mint 1991-ben, amikor a Minimax szerb televízión viccelődött azzal, hogy a csetnik önkéntesei rozsdás kanállal kaszabolják a horvátokat, hogy a patológusok soha ne tudják megállapítani, vajon a tetanusz vagy a csetnikek okozta sebesülések okozták-e a vesztüket. ${ }^{35}$

Az ügyészség fellebbezett, az ügyben másodfokon ítélkező bírói tanácstól tehát várhatjuk az elsőfokú kamara mulasztásainak és hibáinak kiküszöbölését.

\section{Abstract}

Vojislav Šešelj was acquitted by the International Criminal Tribunal for the former Yugoslavia on 31 March 2016. The Trial Chamber of the ICTY assessed evidence on the recruitment of volunteers (who later became perpetrators of international crimes), the defendant's extremist, nationalistic and public hate speeches, and drew the conclusion that he is not responsible for war crimes or crimes against humanity. The present paper discusses gaps and mistakes appearing in the judgement from the point of view of two criminal liability concepts: instigation and aiding and abetting. After briefly summarizing the standards applied by the ICTY, the author presents a re-assessment of the facts referring also to the major arguments of Judge Flavia Lattanzi (dissenting).

$33 \mathrm{http}: / / w w w . b a l k a n i n s i g h t . c o m / e n / a r t i c l e / b a l k a n-w a r-c r i m e-s u s p e c t s-m a i n t a i n-p o l i t i c a l-i n f l u e n c e-12-02-2016$ (2017. 04. 15.).

34 www.balkaninsight.com/en/article/seselj-will-be-arrested-if-enters-croatia-oreskovic-said-08-24-2016 (2017. 09. 01.).

35 www.balkaninsight.com/en/blog/time-travel-with-vucic-and-seselj-02-23-2017 (2017. 09. 01.). 